\title{
A method for the estimation of dietary and microbial protein in duodenal digesta of ruminants
}

\author{
By D. E. BEEVER, D. G. HARRISON, D. J. THOMSON, S. B. CAMMELL \\ AND D. F. OSBOURN \\ The Grassland Research Institute, Hurley, \\ Maidenhead, Berkshire SL6 ${ }_{5} L R$
}

(Received 8 fune 1973 - Accepted ${ }_{5}$ February 1974)

\begin{abstract}
I. A method is described for the estimation of the microbial and dietary protein entering the small intestine of sheep, based on an intraruminal infusion of $\left[{ }^{35} \mathrm{~S}\right]$ sulphate, and isolation of the labelled microbial protein.

2. Samples of the microbial fraction contained in duodenal digesta were isolated by highspeed centrifugation and a scheme of analysis was devised for the determination of the specific activity of the methionine in the microbial fraction and the duodenal digesta.

3. In the absence of dietary methionine in duodenal digesta, it was postulated that the ratio of the specific activities of microbial methionine (M) and digesta methionine (D) should equal $x$. Using two purified diets containing urea as the sole source of nitrogen, the $M: D$ ratio was found to vary from 0.94 to $I .08$ (mean $I \cdot 0 \mathrm{I} \pm 0.0 \mathrm{I}$ ).

4. Addition of known quantities of dietary protein to labelled duodenal digesta obtained from one sheep fed on a non-protein diet increased the M:D ratio. Prediction of the dietary protein present from changes in the $M: D$ ratio gave satisfactory agreement with the amounts of dietary protein known to be present ( $96-101 \%$ of known value, mean $98 \cdot 4 \pm 1 \cdot 24 \%$ ).

5. When animals were fed hourly the $M: D$ ratio remained reasonably constant throughout $24 \mathrm{~h}$. In contrast, with twice-daily feeding the $M: D$ ratio varied markedly throughout the $24 \mathrm{~h}$. However, summation of the estimates made of the flow of microbial and dietary protein into the duodenum in each $2 \mathrm{~h}$ period throughout $24 \mathrm{~h}$ agreed closely with the estimates made from samples withdrawn from the accumulated flow of digesta over the whole $24 \mathrm{~h}$ period.

6. The method was finally adapted to situations with either frequent or infrequent feeding patterns, and the need for a priming infusion period of $\mathrm{I} 6 \mathrm{~h}$ before the collection and sampling of duodenal digesta was established.
\end{abstract}

The major end-products of microbial fermentation in the rumen considered to be of metabolic importance to the host animal are the volatile fatty acids (VFA) and microbial protein. Total rumen VFA production rates have been measured using isotope dilution techniques (Weller, Gray, Pilgrim \& Jones, 1967; Leng, Corbett \& Brett, rg68). With the use of permanent re-entrant cannulas situated at the proximal duodenum (Ash, 1962) it has been possible to measure the net entry of protein (Kay, 1969), carbohydrate (Armstrong \& Beever, I969) and lipids (Lennox, Lough \& Garton, 1968 ) into the small intestine of the sheep. Several techniques have been proposed, and used to estimate the synthesis of microbial protein in vivo (Walker \& Nader, 1968; Smith \& McAllan, 1970) but the limitation of these techniques, particularly when protein of dietary origin enters the duodenum, led to a consideration of an alternative approach based on the use of ${ }^{35} \mathrm{~S}$. The work reported in this paper outlines and tests a proposed method, based on an intraruminal infusion of radioactive sodium sulphate $\left(\mathrm{Na}_{2}{ }^{35} \mathrm{SO}_{4}\right)$, for the quantitative estimation of dietary and microbial protein in duodenal digesta. Preliminary reports of this work have been published (Beever, Harrison \& Thomson, 1972; Harrison, Beever \& Thomson, 1972). 


\section{Theoretical aspects of the proposed method}

Protein entering the small intestine of ruminants is of bacterial, protozoal, dietary and endogenous origin. If the diet contains no protein, then the protein at the duodenum will consist of bacterial, protozoal and endogenous material only, with the microbial protein comprising the major portion. The contribution of protein of endogenous origin to the total protein at the duodenum is normally small (Phillipson, 1964). It has been shown by Henderickx (1961) and Roberts \& Miller (1969) that an infusion of ${ }^{35} \mathrm{~S}$-labelled inorganic sulphate into rumen contents, either in vitro or in vivo yields bacteria and protozoa containing labelled sulphur amino acids. From digesta collected at the duodenum of sheep fitted with re-entrant cannulas it is possible to isolate the labelled microbial protein, and so determine the specific activities of microbial and digesta methionine. If the radioactive counts in the microbial and digesta methionine are $N_{m}$ and $N_{d}$ disintegrations/min, and the corresponding concentrations of methionine are $C_{m}$ and $C_{d}$, then the specific activities are $N_{m} / C_{m}$ and $N_{d} / C_{d}$ respectively, and the ratio of the specific activities (M:D) is given by:

$$
\mathrm{M}: \mathrm{D}=\left(\frac{N_{m}}{C_{m}}\right) /\left(\frac{N_{d}}{C_{d}}\right) \text {. }
$$

If all the methionine of the digesta methionine is of microbial origin, then $N_{m} / C_{m}$ should equal $N_{d} / C_{d}$ and so M:D should equal I. The specific activity of the digesta methionine $\left(N_{d} / C_{d}\right)$ will be reduced in the presence of unlabelled methionine in duodenal digesta, and the M:D ratio will be greater than $\mathrm{I}$. The proportion of microbial methionine in duodenal methionine will be determined by the reciprocal of the ratio and from a knowledge of the concentration of methionine in the microbial and dietary protein and the total protein entering the duodenum, a quantitative estimation of the amounts of microbial and dietary protein present can be made.

To determine the validity of the proposed technique, five criteria were examined.

I. In the absence of dietary protein in duodenal digesta, does the described M:D ratio of specific activities approximate to $\mathrm{I} \cdot \mathrm{O}$ ?

2. The contribution of bacteria and protozoa to total rumen micro-organisms can be altered by the ingestion of different diets (Eadie \& Mann, I970). However, most protozoa appear to be lysed in the abomasum (Pounden, Ferguson \& Hibbs, I950) and do not appear as intact organisms in the microbial fraction isolated from duodenal digesta by high-speed centrifugation. Do rumen microbial populations with different proportions of bacteria and protozoa affect the derived M:D ratio, based on duodenal digesta?

3. As the incorporation of $\left[{ }^{35} \mathrm{~S}\right]$ sulphate into microbial protein may take up to $60 \mathrm{~h}$ to reach equilibrium (K. Hutton, personal communication), does the ratio obtained before and after equilibrium vary significantly ?

4. When varying amounts of dietary protein are added to a labelled duodenal digesta, which contains no dietary protein, do the proportions of dietary protein predicted from the $\mathrm{M}: \mathrm{D}$ ratio agree with the levels of dietary protein added ?

5. Could the proposed method, which depends on the determination of a ratio of 
Table r. Details of the experimental programme

\begin{tabular}{|c|c|c|c|c|c|c|c|}
\hline \multirow[b]{2}{*}{$\begin{array}{l}\text { Expt } \\
\text { no. }\end{array}$} & \multicolumn{3}{|c|}{ Diet } & \multicolumn{2}{|c|}{ Feeding pattern } & \multicolumn{2}{|c|}{$\begin{array}{l}\text { Infusion of } \\
\mathrm{Na}_{2}{ }^{35} \mathrm{SO}_{4}\end{array}$} \\
\hline & Type* & $\begin{array}{l}\text { Physical } \\
\text { form }\end{array}$ & $\begin{array}{l}\text { Method of } \\
\text { adminis- } \\
\text { tration }\end{array}$ & Frequency & $\begin{array}{c}\text { Level } \\
(\mathrm{g} \mathrm{DM} / 24 \mathrm{~h})\end{array}$ & $\begin{array}{c}\text { Rate } \\
(\mu \mathrm{Ci} / \mathrm{h})\end{array}$ & $\begin{array}{l}\text { Duration } \\
\text { (h) }\end{array}$ \\
\hline I & Purified A & Suspension & Infused & Hourly & 700 & 4.5 & 34 \\
\hline 2 & Purified B & Suspension & Infused & Hourlyt & 700 & $4 \cdot 5$ & 34 \\
\hline 3 & Purified A & Pellets & Oral & Hourly† & 700 & 45 & 34 \\
\hline $4 \ddagger$ & Purified A & Pellets & Oral & Hourly $\dagger$ & 500 & 30 & 34 \\
\hline 5 & Purified A & Pellets & Oral & Hourly $\dagger$ & 700 & 3.0 & 18 \\
\hline 6 & Sainfoin & Chopped & Oral & Hourly & 900 & 40 & 120 \\
\hline 7 & Purified B & Pellets & Oral & Hourly† & 700 & $3 \cdot 0$ & 18 \\
\hline 8 & Sainfoin & Chopped & Oral & Twice daily & 900 & $3 \cdot 0$ & 34 \\
\hline & & $\begin{array}{l}\text { DM, d } \\
\text { * See } \\
\dagger \text { An } \\
\pm \text { Wit }\end{array}$ & rotozo & 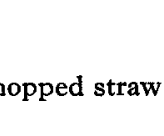 & fed. & & \\
\hline
\end{tabular}

Table 2. Composition of the diets ( $/ \mathrm{kg}$ dry matter) given to the sheep

\begin{tabular}{lcccccc}
\multicolumn{1}{c}{ Diet } & Cellulose & Starch & Sucrose & Urea & Minerals & Nitrogen \\
Purified A & 514 & r 24 & 247 & 75 & 40 & $35 \cdot 0$ \\
Purified B & $\mathbf{3 1 5}$ & $47 \mathbf{I}$ & I17 & $\mathbf{5 6}$ & 40 & $26 \cdot \mathrm{I}$ \\
Sainfoin & 264 & Trace & Trace & - & $91 *$ & $27 \cdot 5$ \\
\multicolumn{7}{c}{ * Ash value. }
\end{tabular}

specific activities, be used with twice-daily feeding where steady-state conditions in the rumen are not maintained?

\section{EXPERIMENTAL}

The sequence of experiments, the diets given, the level and frequency of feeding and the rate and duration of $\mathrm{Na}_{2}{ }^{35} \mathrm{SO}_{4}$ infusion are given in Table $\mathbf{I}$.

\section{Diets}

Table 2 shows the composition of the experimental diets. Two purified diets were prepared; one was of high-cellulose, low-starch composition (diet A) while the other was of low-cellulose, high-starch composition (diet B), with urea as the only source of nitrogen in both diets. Dried, chopped sainfoin (Onobrychis sativa Lam.) was given both frequently (hourly) and infrequently (twice daily) in testing the validity of the proposed technique. All diets were given to Suffolk $\times$ Halfbred wethers, 2 years old and weighing $45^{-} 5^{\circ} \mathrm{kg}$. Each sheep was fitted with a rumen cannula and with reentrant cannulas at the proximal duodenum (Brown, Armstrong \& MacRae, 1968). The sheep were housed in metabolism crates throughout each experimental period and in exercise pens between experiments. A minimum period of $21 \mathrm{~d}$ was allowed for adaptation to each new diet. 


\section{Procedure}

Expt $\mathrm{r}$. Purified diet A (700 g dry matter (DM)) was infused intraruminally as a suspension, with $3 \mathrm{l}$ artificial saliva, $\mathrm{pH}$ 6.8 (McDougall, 1948). The suspension was prepared daily. $\mathrm{Na}_{2}{ }^{35} \mathrm{SO}_{4}$ solution (0.225 $\mu \mathrm{Ci} / \mathrm{ml}$, I $\mathrm{mg} \mathrm{Na}{ }_{2} \mathrm{SO}_{4} / \mathrm{ml}$ ) was constantly infused into the rumen for $34 \mathrm{~h}$ and total duodenal contents were collected every $2 \mathrm{~h}$ during the last $24 \mathrm{~h}$ of the infusion according to the technique of Beever, Thomson, Pfeffer \& Armstrong (1971); twelve individual 2-hourly samples were obtained. Part of each individual sample was used to prepare separate microbial fractions in order that the $\mathrm{M}: \mathrm{D}$ ratio could be obtained. A weight of unlabelled duodenal digesta, equal to the weight of labelled duodenal digesta collected during each $2 \mathrm{~h}$ period, was slowly reintroduced through the distal cannula over the next $2 \mathrm{~h}$.

Expt 2. Purified diet B containing $470 \mathrm{~g}$ starch $/ \mathrm{kg}$ DM was infused intraruminally as a suspension under the same conditions as in Expt 1 , to determine the effect of diet composition on the $M: D$ ratio.

Expt 3. Initially the purified diets were administered as suspensions in Expts $\mathrm{I}$ and 2. Subsequently, the diets were pelleted using a small experimental press and Expt $\mathrm{r}$ was repeated with diet $\mathrm{A}$ given as pellets.

Expt 4. The rumen of a sheep offered diet A pellets was defaunated by the ruminal addition of $5 \mathrm{~g}$ di-octyl sulphosuccinate on 2 consecutive days. Approximately $15 \mathrm{~d}$ later, when the protozoal count in rumen contents was still zero, the infusion, collection and sampling procedures outlined in Table $\mathrm{I}$ and Expt $\mathrm{I}$ were repeated. The level of feeding was, however, reduced $(500 \mathrm{~g} \mathrm{DM} / \mathrm{d})$ as the animal showed reluctance to consume greater amounts.

Expt 5. In this experiment, the rates of incorporation of ${ }^{35} \mathrm{~S}$ into rumen bacteria and rumen protozoa were examined. Most protozoa undergo lysis in the acidic conditions of the abomasum and few intact protozoa reach the duodenum. The specific activities of both bacterial and protozoal methionine must be similar if the separated microbial fraction of duodenal digesta is to be considered representative of microbial protein at the duodenum. One sheep was given $700 \mathrm{~g}$ DM of diet A pellets/d and $\left[{ }^{35} \mathrm{~S}\right]$ sulphate was infused intraruminally for $18 \mathrm{~h}$. Samples of rumen liquor were removed every $2 \mathrm{~h}$ and samples of rumen protozoa and bacteria were isolated by the technique of Iloeller \& Harmeyer (1964). The isolated fractions were assayed for the specific activity of methionine and the rates of incorporation of $\left.{ }^{35} \mathrm{~S}\right]$ sulphate into protozoal and bacterial protein were compared.

Expt 6. In this experiment, the influence of time from initiation of the ${ }^{35} \mathrm{~S}$ infusion on the $\mathrm{M}: \mathrm{D}$ ratios was examined both before and after equilibrium had been reached. Dried, chopped sainfoin ( $900 \mathrm{~g} \mathrm{DM} / \mathrm{d}$ ) was offered in equal amounts every hour. $\mathrm{Na}_{2}{ }^{35} \mathrm{SO}_{4}$ was infused intraruminally for $\mathrm{I} 2 \mathrm{O} \mathrm{h}$ and samples of duodenal digesta were collected every $\mathrm{I} 2 \mathrm{~h}$, each for a period of $\mathrm{I} h$. The individual microbial fractions were isolated in order that the M:D ratios could be obtained. In addition, samples of the duodenal digesta were assayed for the level of radioactivity in the total protein fraction to determine the rate of incorporation of ${ }^{35} \mathrm{~S}$.

Expt 7. During the last $2 \mathrm{~h}$ of an $\mathrm{I} 8 \mathrm{~h}$ intraruminal infusion of $\mathrm{Na}_{2}{ }^{35} \mathrm{SO}_{4}$, labelled 
duodenal digesta was collected from a sheep fed on purified diet $B$. The sample was homogenized to provide six equal samples of $100 \mathrm{ml}$ each. To five samples, $\mathrm{I}, 2,4,8$ or 16 parts of ground sainfoin, known to contain $68 \mathrm{mg}$ amino acid per part, were added; the one remaining sample was used as a blank with no added dietary protein. Individual samples of digesta were homogenized before separation of the individual microbial fractions. Finally, the proportions of dietary and microbial protein were determined and compared with the amounts known to be present.

Expt 8. Expts $1-7$ were conducted on an hourly feeding regimen, when a constant intraruminal infusion could be considered to give steady-state conditions within the rumen. In this experiment, the proposed ratio technique was examined under a twice daily feeding regimen. One sheep was given $900 \mathrm{~g} \mathrm{DM} / \mathrm{d}$ of dried, chopped sainfoin in two equal feeds at 09.00 and 17.00 hours, when chromic oxide-impregnated paper (Corbett, Greenhalgh, McDonald \& Florence, r960) was administered via the rumen cannula. $\mathrm{Na}_{2}{ }^{35} \mathrm{SO}_{4}$ was infused intraruminally for $34 \mathrm{~h}$ and duodenal digesta was collected over the last $24 \mathrm{~h}$, as twelve separate $2 \mathrm{~h}$ samples. In addition, a bulk sample was accumulated on a wet-matter basis (Beever et al. I97I). The thirteen microbial fractions were prepared and the specific activities of these and the corresponding digesta samples were determined. In addition, all digesta samples were analysed for chromic oxide content (Stevenson \& de Langen, 1960) and total N (macro-Kjeldahl). The proportions of microbial and dietary $\mathrm{N}$ were determined in each sample and by the use of chromic oxide as an indigestible flow-marker the total quantities of microbial and dietary $\mathrm{N}$ entering the proximal duodenum were calculated.

\section{Analytical methods}

Isolation of the microbial fraction $(M)$ from duodenal digesta. A representative sample of duodenal digesta $(200 \mathrm{ml})$ was filtered through cheesecloth and the filtrate was centrifuged at $2800 \mathrm{~g}$ for $5 \mathrm{~min}$ to remove food particles. The supernatant fraction was then centrifuged at $20000 \mathrm{~g}$ for $30 \mathrm{~min}$ at $2^{\circ}$ and the residue was resuspended in glass-distilled water and recentrifuged. The final residue was retained and designated the microbial fraction.

Isolation of protozoa and bacteria from rumen liquor. The method used was based on the earlier work of Hoeller \& Harmeyer (1964). Approximately $500 \mathrm{ml}$ of strained rumen liquor was placed in a measuring cylinder and allowed to stand for to min. The top $400 \mathrm{ml}$ was removed and the bacteria were isolated by high-speed centrifugation as described above. The remaining $100 \mathrm{ml}$ in the measuring cylinder was mixed and centrifuged at $100 \mathrm{~g}$ for $60 \mathrm{~s}$. The residue was resuspended in artificial saliva and the centrifugation was repeated until the final product was found, by examination under a microscope, to consist mainly of protozoa.

Measurement of ${ }^{35} S$ content in digesta and microbial methionine. A representative sample of duodenal digesta (approx. $20 \mathrm{ml}$ containing I $50 \mathrm{mg}$ protein), or the microbial fraction obtained from $200 \mathrm{ml}$ duodenal digesta, was hydrolysed in $6 \mathrm{M}-\mathrm{HCl}$ for $2 \mathrm{I} h$ under reflux. Each hydrolysate was allowed to cool, then filtered through acid-washed glass wool. A portion of the filtrate $(25 \mathrm{ml})$ was taken to dryness at $60^{\circ}$ using a rotary evaporator (Buchi, Flawil, Switzerland) and $40 \mathrm{ml}$ performic acid 
$(36 \mathrm{ml}$ formic acid $+4 \mathrm{ml}$ hydrogen peroxide (20 vol.)) was added to the flask and allowed to stand overnight ( $16 \mathrm{~h}$ ) to oxidize the sulphur amino acids (Moore, 1963). Excess performic acid was removed by the addition of $7 \mathrm{ml}$ hydrobromic acid and the contents were dried at $40^{\circ}$ using a rotary evaporator. The contents of the flask were re-dissolved in $5 \mathrm{ml}$ glass-distilled water, adjusted to $\mathrm{pH} 7$ with sodium carbonate, transferred to a Dowex-2 resin column ( $\mathrm{Cl}$ form) (size $180 \times 16 \mathrm{~mm}$ ) and eluted slowly with glass-distilled water in order to remove all traces of inorganic $\left[{ }^{35}\right.$ S $]$ sulphate from the solution. The total eluate (approx. $50 \mathrm{ml}$ ), containing methionine sulphone and cysteic acid, was evaporated to dryness at $40^{\circ}$ on a rotary evaporator, re-dissolved in a further $5 \mathrm{ml}$ of glass-distilled water, transferred to a Dowex-50 resin column $(\mathrm{Na}$ form) (size $180 \times 16 \mathrm{~mm}$ ) and eluted with water to remove the cysteic acid, which was discarded. The column was then eluted with $0.0 \mathrm{I} \mathrm{M}-\mathrm{HCl}(4 \circ \mathrm{ml})$ and the eluate containing methionine sulphone was evaporated to dryness at $40^{\circ}$ on a rotary evaporator and finally re-dissolved in $5 \mathrm{ml}$ of buffer solution $\left(\mathrm{pH}^{2} \cdot 9\right.$ ) containing taurine as an internal standard. The concentration of methionine as methionine sulphone was assayed with a Technicon N.C. I Automatic Amino Acid Analyzer using a short column $(\mathrm{I} \cdot 3 \mathrm{~m})$ with resin type $\mathrm{C}_{2}$. Levels of ${ }^{35} \mathrm{~S}$ and radioactivity in all solutions were determined by liquid scintillation with a toluene-Triton $\mathrm{X}$ scintillant $(4 \mathrm{~g}$ diphenyloxazole (PPO) + 0. I g I,4-bis, 2-(phenyloxazolyl)-benzene (POPOP)) dissolved in I 1 of toluene plus $860 \mathrm{ml}$ Triton X-100 (Downes, Reis, Sharry \& Tunks, 1970). Scintillant volume was $10 \mathrm{ml}$ and sample volume did not exceed I ml.

Incorporation of ${ }^{35} \mathrm{~S}$ into duodenal protein. Individual samples of duodenal digesta were extracted with trichloroacetic acid (TCA) to isolate the protein fraction. Initial extraction of $20 \mathrm{ml}$ digesta at room temperature with $10 \mathrm{ml}$ TCA $(\mathrm{I} 00 \mathrm{~g} / \mathrm{l})(\times \mathrm{I})$ and $5 \mathrm{ml}$ TCA $(5 \circ \mathrm{g} / \mathrm{l})(\times 2)$ was followed by a further extraction with $5 \mathrm{ml} \mathrm{TCA}(5 \circ \mathrm{g} / \mathrm{l})$ $(\times \mathrm{I})$ at $90^{\circ}$ for $30 \mathrm{~min}$. After cooling and centrifugation, the residue was further extracted with $5 \mathrm{ml} \mathrm{TCA}\left(5^{\circ} \mathrm{g} / \mathrm{l}\right)(\times 3), 5 \mathrm{ml}$ ethanol $(\times 2), 5 \mathrm{ml}$ chloroformethanol $(3: \mathrm{I}, \mathrm{v} / \mathrm{v})(\times 2)$ and $5 \mathrm{ml}$ diethyl ether $(\times 2)$ to give a brown precipitate. This was shaken for 5 min with $5 \mathrm{ml} \circ \cdot \mathrm{I} \mathrm{M}-\mathrm{NaOH}$, centrifuged until clear, and the resulting solution was assayed for ${ }^{35} \mathrm{~S}$ content by liquid scintillation. The total protein content was estimated by measurement of the extinction at $280 \mathrm{~nm}$ and the final results were expressed as ${ }^{35} \mathrm{~S}$ disintegrations/min per unit extinction at $280 \mathrm{~nm}$.

Efficiency of separation of methionine sulphone from other sulphur-containing moieties. Following performic acid oxidation, the sulphur-containing moieties in the hydrolysates comprise methionine sulphone, cysteic acid, and inorganic sulphate, all of which will contain some radioactivity. To avoid over-estimation of the level of radioactivity of the methionine sulphone, the cysteic acid and inorganic sulphate must be removed. Up to $100 \mathrm{mg}$ of $\mathrm{Na}_{2} \mathrm{SO}_{4}$, containing $0^{\cdot} 5^{-1} \cdot{ }^{\circ} \mu \mathrm{Ci}{ }^{35} \mathrm{~S}$, were placed on a Dowex-2 resin column ( $\mathrm{Cl}$ form) and the column was eluted with glass-distilled water as described previously. Radio-assay of the eluates obtained from the column indicated that the level of radioactive counts did not differ significantly from the background counts, illustrating that the retention of radioactive sulphate on the column was satisfactory. Similarly, known amounts of cysteic acid (up to Io $\mathrm{mg}$ ) were placed on a Dowex-50 resin column ( $\mathrm{Na}$ form) and eluted with glass-distilled water. Recovery of the added 
Table 3. Expts $1-4$. The ratio of the specific activities of microbial methionine $(M)$ and digesta methionine $(D)(M: D)$ obtained at 1o $h$ intervals for two protein-free purified diets

\begin{tabular}{|c|c|c|c|c|c|}
\hline \multirow[b]{3}{*}{ Expt no. } & \multicolumn{4}{|c|}{ (Each value is the mean of two analyses) } & \multirow[b]{3}{*}{ SEM } \\
\hline & \multicolumn{3}{|c|}{ Ratio after infusion for: } & \multirow[b]{2}{*}{ Mean } & \\
\hline & Ioh & $20 \mathrm{~h}$ & $3 \circ \mathrm{h}$ & & \\
\hline I & 0.94 & 0.94 & 0.99 & 0.96 & 0.015 \\
\hline 2 & 1.08 & $1 \cdot 04$ & $1 \cdot 06$ & I.06 & 0.011 \\
\hline 3 & 0.99 & 0.99 & 1.08 & $I \cdot 02$ & 0.022 \\
\hline $4^{*}$ & $I \cdot O I$ & I.04 & 0.97 & $I \cdot O I$ & 0.014 \\
\hline
\end{tabular}

cysteic acid, in the column eluate, was $97 \%$, and was shown to be unaffected by the presence of methionine sulphone. Addition of methionine sulphone (1 $\mathrm{mg}$ ) to a similar column indicated complete retention when eluted with water, but recovery of more than $95 \%$ when eluted with $0.0 \mathrm{r} \mathrm{M}-\mathrm{HCl}$.

\section{RESULTS}

Expts $\mathrm{I}-4 . M: D$ ratios obtained with purified diets containing no protein

The results obtained during the periods $10-12,20-22$ and $30-32 \mathrm{~h}$ after the start of the infusion are given in Table 3 . There was no significant difference between the results obtained from any of the three diets (Expts $I-3$ ), the mean values of $0.96, \mathrm{I} \cdot 06$ and $I .02$ being close to the expected theoretical value of $I \cdot 0$. Similarly, within each experiment, there was no apparent trend in the ratios obtained at the different sampling intervals. In Expt 4, where the rumen contained no protozoa, neither the mean $M: D$ ratio $(x \cdot O I)$ nor the three individual $M: D$ ratios deviated significantly from the theoretical value of $I \cdot O$. The observed mean of $x \cdot 0 r$ for the twelve estimates of Expts $1-4$ did not deviate significantly from the theoretical value of $\mathrm{r} \cdot 0$.

\section{Expt 5. Rate of incorporation of ${ }^{35} S$ into rumen bacteria and protozoa}

The specific activities of the methionine of isolated rumen bacteria and protozoa (Fig. I) increased in a sigmoid manner and achieved similar plateau values of specific activity at $12 \mathrm{~h}$ and $16 \mathrm{~h}$ respectively after the start of the infusion. The rate of incorporation by the protozoa was clearly shown to be much slower than that recorded for the bacteria for purified diet A (high cellulose).

\section{Expt 6. Incorporation of ${ }^{35} S$ into digesta protein}

The results of Expt 6 are presented in Figs 2 and 3. Fig. 2 illustrates the increase in incorporation of ${ }^{35} \mathrm{~S}$ (disintegrations/min per unit extinction $280 \mathrm{~nm}$ ) into digesta protein with time. The rate of incorporation increased markedly over the first $36 \mathrm{~h}$, finally achieving a plateau value at approximately $48 \mathrm{~h}$. The M:D ratios obtained for each sample are illustrated in Fig. 3. There was a slight variation around the mean value 


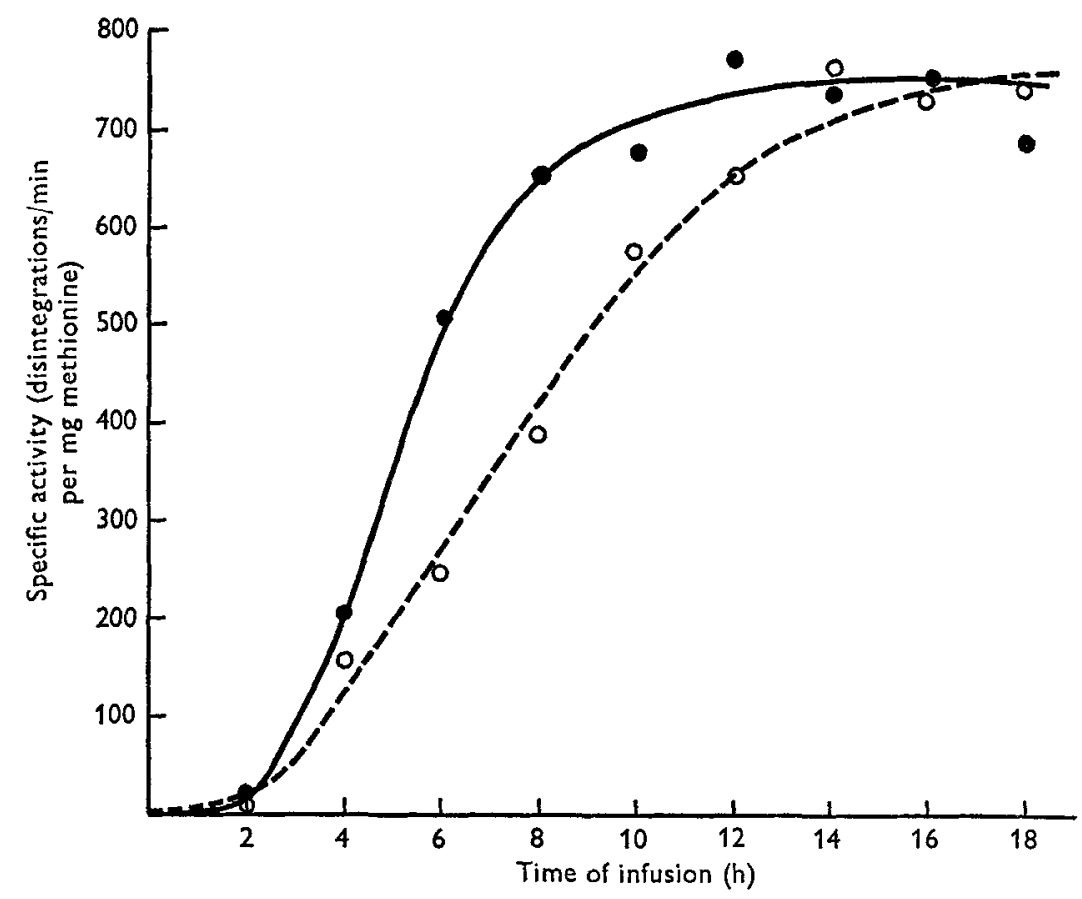

Fig. x. Expt 5. Incorporation of ${ }^{35} \mathrm{~S}$ into rumen bacteria $(-)$ and protozoa (-- ) in sheep.

$(2.56 \pm 0.05)$ but the mean values obtained from the parts of the curve before and after equilibrium had been reached $(2.57 \pm 0.08$ and $2.55 \pm 0.08$ respectively) showed excellent agreement.

\section{Expt 7. Evaluation of the technique to estimate the quantity of dietary protein present in duodenal digesta}

The proportions of dietary protein in a series of labelled duodenal digesta estimated from the $\mathrm{M}: \mathrm{D}$ ratio are illustrated in Table 4 , and compared with the amounts known to be present. The derived values ranged from $96-101 \%$ of the known amount of protein present (mean $98 \%$ ) and this agreement was considered to be acceptable. One possible cause of error was attributed to the nature of the dietary protein present, which was clearly different from undigested food particles normally isolated at the duodenum, and tended to contaminate the microbial fractions isolated by high-speed centrifugation. The level of contamination was, however, small as can be seen from the specific activities of the isolated microbial methionine (Table 4 ). With no added dietary protein, the specific activity was $1 \cdot 96 \times 10^{6}$ disintegrations $/ \mathrm{min}$ per $\mathrm{mg}$ methionine and this did not deviate significantly from the mean of six samples, $1.94 \pm 0.04$. At the highest level of dietary addition there was a small reduction in specific activity of the microbial methionine ( $(\cdot 75)$, suggesting some degree of contamination. 
Vol. 32



Fig. 2. Expt 6. Rate of incorporation of ${ }^{96} \mathrm{~S}$ into duodenal protein during a $120 \mathrm{~h}$ continuous infusion period in sheep.

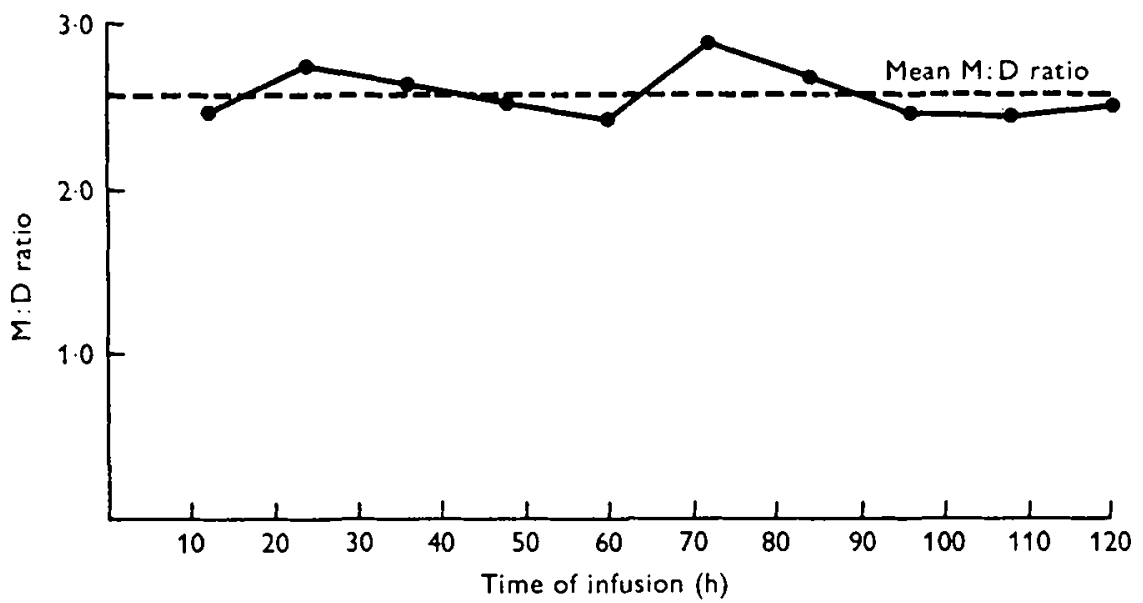

Fig. 3. Expt 6. Changes in the ratio of specific activities of ${ }^{95} \mathrm{~S}$ in microbial (M) and digesta (D) protein ( $M: D$ ratio) with respect to time, when sainfoin was offered hourly to sheep. --, mean $\mathrm{M}: \mathrm{D}$ ratio.

Table 4. Proportions of dietary protein in a labelled duodenal digesta of sheep estimated from the $M: D$ ratio*, and compared with the known amounts present

Amount of dietary Percentage of dietary protein:

protein added

(1 part $=68 \mathrm{mg}$ amino acid)

0
I
2
4
8
16

None

$54 \cdot 0$

$70 \cdot 1$

$82 \cdot 5$

$90 \cdot 4$

94.9

$\overbrace{\begin{array}{c}\text { Known } \\ \text { value }(a)\end{array}}^{\begin{array}{c}\text { Estimated } \\ \text { value }(b)\end{array}}$

Specific activity of microbial methionine $\left(\times 10^{\circ}\right.$ disintegrations/min $b / a(\%) \quad$ per $\mathrm{mg}$ methionine)

\begin{tabular}{cr}
$b / a(\%)$ & per mg meth \\
- & 1.96 \\
101.3 & 2.00 \\
99.4 & 2.04 \\
97.1 & 1.88 \\
\hline & 2.00 \\
95.7 & 1.75
\end{tabular}

- Ratio of specific activities of ${ }^{35} \mathrm{~S}$ in microbial protein (M) and digesta protein (D). † Sample of digesta lost. 


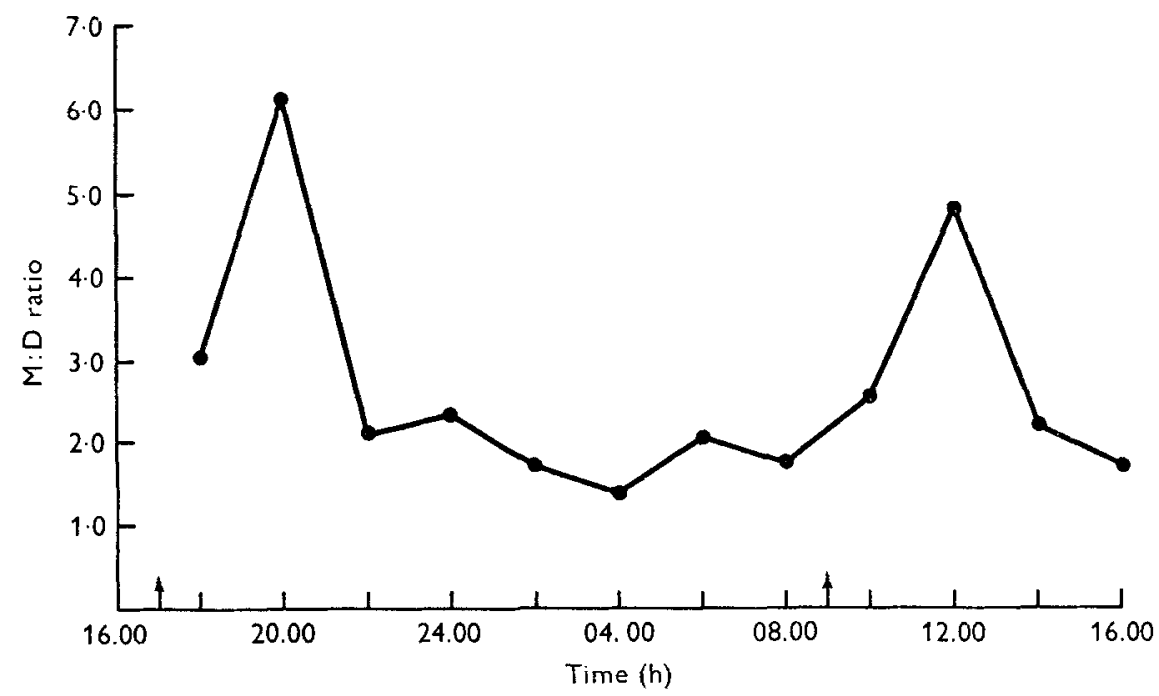

Fig. 4. Expt 8. Changes in the ratio of specific activities of ${ }^{35} \mathrm{~S}$ in microbial (M) and digesta (D) protein ( $M: D$ ratio) throughout a $24 \mathrm{~h}$ period when sainfoin was offered twice daily to sheep. $\uparrow$, Fed.

\section{Expt 8. Adaptation of the ratio technique to twice-daily feeding}

The changes in the M:D ratios obtained for the twelve individual samples are illustrated in Fig. 4. As the proportion of microbial methionine in duodenal methionine is equivalent to the reciprocal of the $M: D$ ratio, it can be seen that the material passing during the period 22.00-08.00 hours was relatively richer in microbial methionine than that passing in the two periods after feeding when a substantial increase in the quantity of dietary methionine was noted.

The flow of total $\mathrm{N}$ corrected to $100 \%$ recovery of chromic oxide and the flow of microbial and dietary N, estimated from the M:D ratios, are illustrated in Fig. 5.

The flow of total $\mathrm{N}$ increased during the overnight period, with similar fluctuations in the flow of microbial $\mathrm{N}$ and dietary $\mathrm{N}$. The total quantities of microbial and dietary $\mathrm{N}$ entering the duodenum per $24 \mathrm{~h}$ were summated from the individual samples ( 9.8 and $18.8 \mathrm{~g} \mathrm{~N}$ respectively) and agreed closely with the values obtained for the bulked $24 \mathrm{~h}$ sample $\left(9^{\circ} 9\right.$ and $18.6 \mathrm{~g} \mathrm{~N}$ respectively).

\section{DISCUSSION}

\section{Methods of estimation of microbial protein}

$\alpha-\epsilon$-Diaminopimelic acid (DAPA) found only in bacterial cell walls has been used by Hogan \& Weston (1967) and Hutton, Bailey \& Annison (1971) to estimate the quantity of microbial protein entering the small intestine of ruminants, and Smith \& McAllan (1970, 1971) have considered the quantity of nucleic acids at the duodenum to be a measure of microbial protein synthesis. The technique using DAPA, however, estimates only bacterial $\mathrm{N}$, as Virtanen (1967) has shown DAPA to be absent from protozoa. The results obtained from DAPA analysis may be affected by the constancy 


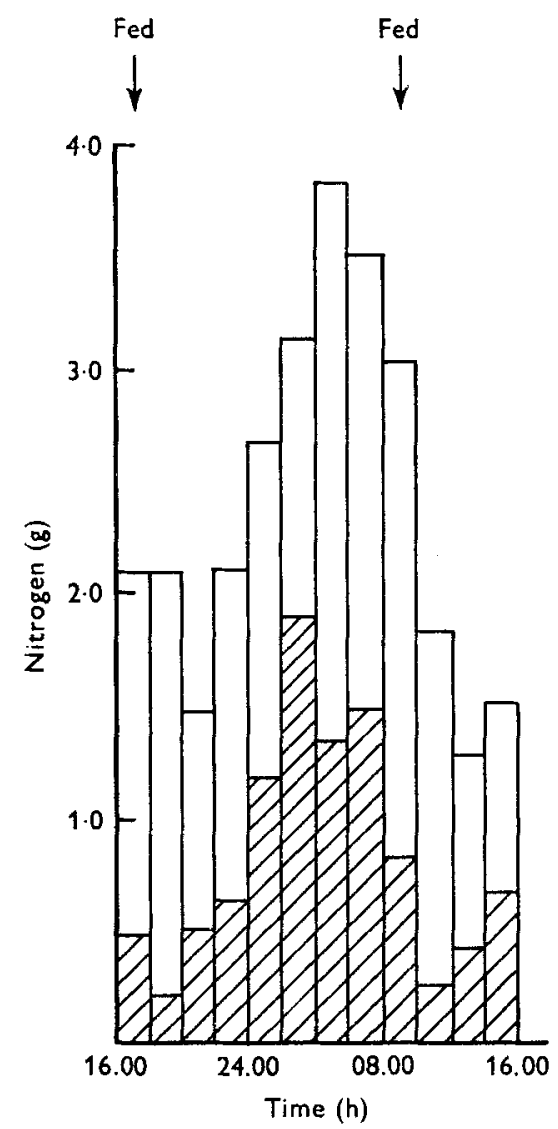

Fig. 5. Expt 8. Changes, during a $24 \mathrm{~h}$ period, in the quantities (g) of dietary and microbial nitrogen entering the small intestine of a sheep offered sainfoin twice daily. $\square$, dietary $N$;

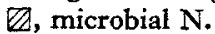

of the ratio, DAPA:total bacterial $\mathrm{N}$ or protein between bacterial species, and Rose (1968) has observed that some bacterial species do not contain DAPA. The technique using nucleic acids relies on the assumption that dietary nucleic acids are rapidly degraded in the rumen, thus assuming all the nucleic acids at the duodenum to be of microbial origin (Smith \& McAllan, 1970). This assumption is based on the observation by these workers that purified nucleic acids added to the rumen were rapidly degraded and disappeared completely within $4 \mathrm{~h}$. Though the application of this technique may be valid when the dietary protein is highly soluble, it may be incorrect when large portions of the dietary protein and nucleic acids have been rendered insoluble by exposure to heat or chemical treatment and pass to the duodenum.

The technique described in the present paper is based on the work of Henderickx (1961) and Walker \& Nader (1968), who attempted to measure microbial protein synthesis in vitro using ${ }^{35} \mathrm{~S}$, and the work of Roberts \& Miller (1969). The results from our studies using purified diets containing no protein indicated that the microbial 
fraction isolated by high-speed centrifugation was representative of the whole population with respect to the specific activity of methionine and that our proposed hypothesis was correct. Subsequent work indicated that after an intra-ruminal infusion of ${ }^{35} \mathrm{~S}$, the rumen bacteria and protozoa had reached similar specific activities of methionine after a period of $\mathrm{x} 6 \mathrm{~h}$. The slower rate of increase in specific activity of the protozoa agreed with the known slower metabolism of protozoa compared with bacteria (Hungate, I966). As a consequence, in later work an infusion period of $16 \mathrm{~h}$ was used before sampling the digesta from the duodenum, albeit few protozoa are thought to survive intact in passage through the abomasum. In a recent paper Leibholz (1973) adopted a technique similar to the one proposed, with an intraruminal infusion of inorganic ${ }^{35} \mathrm{~S}$ and isolation of the ${ }^{35} \mathrm{~S}$-containing amino acids of microbial protein. The specific activities of cysteic acid in duodenal and bacterial protein were assayed, and comparison of these indicated the proportion of microbial protein in duodenal protein. One limitation of this work appears to be the failure to make corrections for the differing cysteic acid content of microbial and dietary protein.

\section{Accuracy of the proposed technique}

The accuracy of the technique is clearly dependent upon the errors associated with determining the specific activities of the microbial and digesta methionine. The degree of purity of the separated microbial fraction will influence the accuracy of the technique. Results from Expt 7 suggest that even with high levels of dietary protein, the level of food contamination in the isolated microbial fraction was minimal. Possible errors associated with the two-column technique may be considered to be small. As the proposed technique is based on a ratio of specific activities, a quantitative recovery of the sulphur amino acids from the columns is not essential. The only possible source of error associated with the use of resin columns would be the presence of $\left.{ }^{35} \mathrm{~S}\right]$ sulphate in the column eluate, which would lead to an over-estimation of specific activity. However, earlier work indicated that the capacity of the column (Dowex-2) to remove ${ }^{35} \mathrm{SO}_{4}$ was greater than the amounts encountered with digesta or microbial hydrolysates. Furthermore, in practice, a small sample of all column eluates was tested for the presence of inorganic sulphate with barium hydroxide and all results indicated efficient retention of sulphate on the resin column.

Likely errors due to the assay of methionine are specified as $\pm 2.5 \%$ (Technicon Instruments, Basingstoke) whilst errors associated with liquid scintillation counting would be of the order of $\pm 3 \%$.

\section{Possible limitations to proposed technique}

Though the technique based on ${ }^{35} \mathrm{~S}$ appears to be valid, and has been adapted successfully to infrequent feeding, possible limitations to the method must be considered. The validity of estimating methionine in the microbial and dietary protein at the duodenum relies on the assumption that the amino acid composition of undegraded dietary protein present at the duodenum is similar to that of the food offered. Evidence on this aspect is very limited. Secondly, if dietary methionine is incorporated 
direct into microbial protein, then the proportion of microbial protein in duodenal protein will be underestimated. Clearly, these two fields of interest require immediate further study.

Decreases in the specific activity of the duodenal methionine are attributable to the presence of unlabelled methionine. Though this is largely of dietary origin, it must be noted that unlabelled methionine of endogenous origin will also be included. It is unlikely that endogenous secretions of methionine will be either large or highly labelled with ${ }^{35} \mathrm{~S}$. Therefore the presence of such methionine will tend to slightly over-estimate the quantity of dietary methionine present, but the mean $M: D$ ratio of $\mathrm{I} \cdot$ 이 for all purified diets containing no protein would indicate that the quantity of endogenous methionine is insignificant.

Whilst the proposed method appears capable of giving reliable estimates of microbial protein synthesis, the labour requirements during infusion periods and continuous sampling are high. However, with the limitations of other techniques, it appears essential to apply this technique to a wide range of dietary situations, and at the same time consider possible relationships with the levels of DAPA, nucleic acids or other microbial markers.

The authors record their thanks to Mrs M. Hoare, Mr D. C. Davies (IRAD, Compton) and Dr P.S. Bramley for the surgical preparation and veterinary supervision of the sheep, to Mr W. T. B. Marchant (NIAE, Silsoe) for preparation of the pelleted diets, and to Mr J. S. Fenlon for mathematical assistance.

\section{REFERENCES}

Armstrong, D. G. \& Beever, D. E. (I969). Proc. Nutr. Soc. 28, 121. Ash, R. W. (1962). Anim. Prod. 4, 309.

Beever, D. E., Harrison, D. G. \& Thomson, D. J. (1972). Proc. Nutr. Soc. 3r, 6I A.

Beever, D. E., Thomson, D. J., Pfeffer, E. \& Armstrong, D. G. (197I). Br. F. Nutr. 26, 123.

Brown, G. F., Armstrong, D. G. \& MacRae, J. C. (1968). Br. vet. F. 124, 78.

Corbett, J. L., Greenhalgh, J. F. D., McDonald, I. \& Florence, E. (1960). Br. F. Nutr. 14, 289.

Downes, A. M., Reis, P. J., Sharry, L. F. \& Tunks, D. A. (1970). Br. F. Nutr. 24, 1083.

Eadie, J. M. \& Mann, S. O. (1970). In Physiology of Digestion and Metabolism in the Ruminant p. 335 [A. T. Phillipson, editor]. Newcastle upon Tyne: Oriel Press.

Harrison, D. G., Beever, D. E. \& Thomson, D. J. (1972). Proc. Nutr. Soc. 3r, 60A.

Henderickx, H. (1961). Archs int. Physiol. Biochim. 69, 449.

Hoeller, H. \& Harmeyer, T. (1964). Zentbl. VetMed. A Ir (3), 244.

Hogan, J. P. \& Weston, R. H. (1967). In Physiology of Digestion and Metabolism in the Ruminant p. 474 [A. T. Phillipson, editor]. Newcastle upon Tyne: Oriel Press.

Hungate, R. E. (1966). In The Rumen and Its Microbes. New York and London: Academic Press.

Hutton, K., Bailey, F. J. \& Annison, E. F. (I971). Br. F. Nutr. 25, I65.

Kay, R. N. B. (I 969). Proc. Nutr. Soc. 28, 140.

Leibholz, J. (1973). Aust. F. agric. Res. 23, 1073.

Leng, R. A., Corbett, J. L. \& Brett, D. J. (1968). Br. F. Nutr. 22, 57.

Lennox, A. M., Lough, A. K. \& Garton, G. A. (I968). Br. F. Nutr. 22, 237.

McDougall, E. J. (1948). Biochem. Y. 32, 99.

Moore, S. (1963). F. biol. Chem. 238, 235.

Phillipson, A. T. (1964). In Mammalian Protein Metabolism Vol. I, p. 7 I [H. N. Munro and J. B. Allison, editors]. London: Academic Press.

Pounden, W. D., Ferguson, L. C. \& Hibbs, J. W. (1950). F. Dairy Sci. 33, 565.

Roberts, S. A. \& Miller, E. L. (r969). Proc. Nutr. Soc. 28, 32 A. 
Rose, A. H. (1968). Chemical Microbiology. London: Butterworth.

Smith, R. H. \& McAllan, A. B. (1970). Br. F. Nutr. 24, 545.

Smith, R. H. \& McAllan, A. B. (197r). Br. F. Nutr. 25, I8r.

Stevenson, A. E. \& de Langen, H. (1960). N.Z. Fl agric. Res. 3, 314.

Virtanen, A. L. (1967). Ned. Melk-en Zuiveltijdschr. 21, 223.

Walker, D. J. \& Nader, C. J. (1968). Appl. Microbiol. 16, I 124.

Weller, R. A., Gray, F. V., Pilgrim, A. F. \& Jones, G. B. (1967). Aust. F. agric. Res. 18, 107. 